\title{
Control of Nonnative Invasive Woody Plant Species at Jamaica Bay Wildlife Refuge, New York City
}

\author{
Richard Stalter, Dwight Kincaid, and Michael Byer
}

\begin{abstract}
Jamaica Bay Wildlife Refuge (JBWR) is situated within Jamaica Bay, an inlet of the Atlantic Ocean at the western end of Long Island, New York, U.S. (40 $35^{\prime} \mathrm{N}$ latitude, $72^{\circ} 52^{\prime} \mathrm{W}$ longitude) within Brooklyn and Queens, boroughs of New York City. The vouchered vascular flora of the refuge consists of 456 species within 270 genera and 90 families of which 222 species, $49 \%$ of the flora, are nonnative. The most aggressive woody alien species are tree of heaven (Ailanthus altissima), Oriental bittersweet (Celastrus orbiculatus), multiflora rose (Rosa multiflora), Russian olive (Elaeagnus angustifolia), autumn olive (E. umbellata), buckthorn (Rhamnus frangula), Japanese honeysuckle (Lonicera japonica), and porcelain berry (Ampelopsis brevipedunculata). Ailanthus altissima, Ampelopsis brevipedunculata, and Celastrus orbiculatus are the most aggressive of the aforementioned aliens. These and additional woody nonnative vascular species can be removed from small areas of a few square meters by cutting, herbicide treatment or hand-pulling. It may be impossible to control, much less eradicate these alien invasives from Jamaica Bay Wildlife Refuge. This article presents guidelines for a scientific and experimental approach to this problem.

Key Words. Ailanthus altissima; Ampelopsis brevipedunculata; Celastrus orbiculatus; Elaeagnus spp.; Jamaica Bay Wildlife Refuge; Lonicera japonica; New York City; Nonnative Vascular Plants; Rhamnus frangula; Rosa multiflora.
\end{abstract}

Jamaica Bay Wildlife Refuge (JBWR) is situated within Jamaica Bay, at $40^{\circ} 35^{\prime} \mathrm{N}$ Latitude, $72^{\circ} 52^{\prime} \mathrm{W}$ Longitude. Jamaica Bay is an inlet of the Atlantic Ocean at the west end of Long Island, New York, U.S. (Stalter and Lamont 2002). JBWR contains 1,905 hectares of upland habitat including freshwater ponds, surrounded by 3,105 hectares of Jamaica Bay. Few changes in the islands and water of Jamaica Bay occurred during the two centuries following the arrival of the first European settlers in 1651. In the twentieth century, the topography of Jamaica Bay was significantly altered by dredging channels and filling marshes in the bay and along its periphery. Almost all of the land that today comprises JBWR was originally salt marsh. Much of this marsh was covered with sediments dredged from the bottom of the bay to create upland habitat (Black 1981). Thus the terrain of the entire upland landform is largely the result of human activities.

In 1972, Jamaica Bay Wildlife Refuge was transferred to the newly created Gateway National Recreation Area, the United States' first urban national park, under the auspices of the National Park Service, U.S. Department of the Interior. Families of a high percentage of nonnative plants are the Caryophyllaceae, Brassicaceae, and Polygonaceae (Stalter and Lamont 2002). The vascular flora of JBWR consists of 456 species within 270 genera and 90 families (Table 1). Two hundred twenty-two species, $49 \%$ of the flora are not native to the region (Gleason and Cronquist 1991) or the refuge. Nonnative species are numerous in the flora of Jamaica Bay and occur primarily at disturbed sites and along the edges of trails and roadsides. Families with the greatest number of nonnative species occur in Poaceae (20 species) and Asteraceae (27 species).

Seven plant communities at JBWR included:

1. Salt Marsh. Salt marshes at Jamaica Bay are dominated by grasses and succulent dicotyledons. These plants can toler- ate water and soil salinity and tidal flooding. No nonnative taxa were found here.

2. Maritime Beach and Poorly Developed Dune. The vascular plant species within this community can tolerate high concentrations of salt spray. Only one nonnative, Russian thistle (Salsola kali), was identified in this community.

3. Thickets and Successional Shrubland. This community contains the largest number of woody plant species. Several nonnative woody taxa occur here and are discussed later.

4. Early Successional Woodland. Stalter and Lamont (2002) describe this community as "poorly developed" at JBWR. Few trees here exceed fifty-years-old.

5. Successional Fields. This contains the largest number of forbs and grasses at JBWR. Though shrubs have invaded the successional fields, including a number of nonnative taxa, they are present in low frequency and are uncommon.

6. Freshwater Wetlands and Moist to Wet Meadows. The artificially created freshwater wetlands, including West Pond, St. John's Pond, and moist to wet meadows are characterized by a flora found nowhere else at JBWR. Species diversity at these sites is high due to the migrating moisture gradients from periods of high rainfall and drought.

7. Ruderal. This community includes disturbed sites around buildings, gardens, lawns, paths, and roadside rights-ofway. Nonnative vascular plant species dominate this community.

Wildlife enthusiasts treasure the Jamaica Bay Wildlife Refuge because they can observe unusually large numbers of both migratory and resident bird species. The layout of 
Table 1. Place of origin of some introduced native and nonnative plants, Jamaica Bay Wildlife Refuge, New York. Native status according to Gleason and Cronquist (1991) and Rheder (1940). Asterisks indicate nonnative status. Nonnative taxa are listed first $(*)$, followed by native taxa; both are in alphabetical order.

\begin{tabular}{|c|c|c|}
\hline Species & Common name & Place of origin \\
\hline *Buddleja davidii & butterfly bush & China \\
\hline *Campsis radicans & trumpet creeper & Southeastern United States \\
\hline *Catalpa bignonioides & catalpa & Southern United States \\
\hline *Ligustrum vulgare & privet & Europe \\
\hline *Mentha spicata & mint & Eastern United States \\
\hline *Narcissus sp. & narcissus & Europe \\
\hline *Pinus thunbergiana & Japanese black pine & Asia \\
\hline *Pyrus communis & pear & Eurasia \\
\hline *Robinia pseudoacacia & black locust & Pennsylvania (and southward) \\
\hline *Rosa canina & dog rose & Europe \\
\hline *Salix pentandra & bay-leaved willow & Europe \\
\hline *Sambucus racemosa var. pubens & elderberry & Northeastern United States \\
\hline *Weigelia japonica & weigelia & Asia \\
\hline *Yucca filamentosa & bear grass & Maryland to Florida \\
\hline Aronia prunifolia & purple chokeberry & Eastern United States \\
\hline Asclepias tuberosa & butterfly bush & Eastern United States \\
\hline Baptisia tinctoria & wild indigo & Eastern United States \\
\hline Crataegus phaenopyrum & hawthorne & Eastern United States \\
\hline Crataegus succulenta & hawthorne & New England to Pennsylvania \\
\hline Gleditsia triacanthos & honeylocust & Eastern United States \\
\hline Ilex glabra & inkberry & Eastern United States \\
\hline Lindera benzoin & spice bush & Eastern United States \\
\hline Liquidambar styraciflua & sweetgum & Eastern United States \\
\hline Opuntia humifusa & prickley pear & Eastern United States \\
\hline Pyrus coronaria & crabapple & Eastern United States \\
\hline Quercus phellos & willow oak & Eastern United States \\
\hline Quercus rubra & red oak & Eastern United States \\
\hline Sambucus canadensis & elderberry & Eastern United States \\
\hline Vaccinium corymbosum & high bush blueberry & Eastern United States \\
\hline
\end{tabular}

trails and ponds make ideal conditions for observation. Other noteworthy wildlife species are also present, such as the Diamond-backed terrapin (Malaclemys terrapin) which is the subject of a long-term study of its population dynamics.

The objectives of the present study were to: 1) identify nonnative invasive woody vascular plant species, 2) determine which woody and herbaceous vascular plant species were most problematic, and 3 ) establish procedures to control the problematic woody taxa.

Most invasive plant species are exotic, but relatively few of all exotics are invasive. Invasive species are those that outcompete native species and take over their habitats. By doing so, they reduce biodiversity. They may completely alter ecosystem function. Lack of enemies or competitors in their new environment may often allow them to spread rapidly. Invasive vascular plants may threaten the existence of rare, threatened or endangered species by out-competing them or altering their habitat. Occasionally, invasive vascular plants may destroy the identity of native species by hybridizing with them.

\section{METHODS}

The present report was an outgrowth of continuing research at Jamaica Bay Wildlife Refuge by the senior author from 1985 to present. This research consisted of observations, collections of more than 800 vouchered specimens and accumulation of information on abundance and habitat preference for each vascular plant spe- cies at JBWR. Problematic specimens were sent to taxonomic experts at the New York Botanical Garden, Brooklyn Botanic Gardens and the New York State Museum for identification. Voucher specimens were deposited at the Gateway National Recreation Area, Herbarium, Fort Wadsworth (Staten Island, New York).

\section{RESULTS AND DISCUSSION}

Following accepted horticultural practices at the time, 33 species (Table 1) were introduced into the refuge by Superintendent Johnson (Kaltman 1968). Seventeen of these species are native to the region, but not to the refuge, while 16 species are not native. In the 1960s when researchers were not as aware of the problems posed by nonnative plants, Superintendent Herbert Johnson, a horticulturalist, was responsible for numerous plantings at the refuge, including nonnative species such as Elaeagnus spp., Japanese black pine (Pinus thunbergiana), firethorn (Pyracantha coccinea), Rosa multiflora, and rugose rose (Rosa rugosa). Johnson also planted native species, including bayberry (Myrica pensylvanica), and choke berry (Aronia spp.) (Venezia and Cook 1991).

Of the five alien tree species, nine nonnative shrubs and one vine introduced by Superintendent Johnson, only Pinus thunbergiana, Rosa multiflora and Lonicera japonica are represented by large numbers of individuals at JBW in 2007 (Table 1). Lonicera japonica is not as abundant as invasive Ampelopsis brevipedunculata and Celastrus orbiculatus; it is a problem locally within thickets and woodlands. 
Of all the nonnative trees and shrubs planted by Johnson at JBWR in the 1960s, only Lonicera japonica and Rosa multiflora posed a threat to native vegetation in 2007. The most widely planted tree by Johnson, Pinus thunbergiana has been declining because of blight.

Eight additional herbaceous nonnative species of concern are also listed in Table 2. Only the three most abundant are treated here. Mugwort (Artemisia vulgaris) is common in fields and pathsides; this weed could be eradicated locally by selective herbicide treatment or by hand-pulling. Tall reed (Phragmites australis) is common around the man-made ponds. Phragmites may be controlled (but probably never eradicated) by RoundUp treatment at anthesis (flowering). Garlic mustard (Alliaria petiolata) is common in woodlands, and is green the year-round. Experimental spraying in selected plots where Alliaria petiolata occurs might be an effective way of controlling this alien. Spraying should be done in early spring before other herbaceous plants emerge from winter dormancy. Infection by powdery mildew (Erysiphe cruciferarum) has shown to control the growth and fitness of Alliaria petiolata in Ohio (Enright and Cipollini 2007).

Table 2. Invasive nonnative plants of concern and their mode of dispersal at Jamaica Bay Wildlife Refuge. Species are listed alphabetically by Latin name followed by the common name. Mode of Dispersal: B-Birds; M-Mammals; S-Soil; W-Wind; Wa-Water.

\begin{tabular}{|c|c|c|c|c|c|}
\hline Ailanthus altissima & tree of heaven & W & & & \\
\hline Alliaria petiolata & garlic mustard & B & S & & \\
\hline Ampelopsis brevipedunculata & porcelain berry & $\mathrm{B}$ & & & \\
\hline Artemisia vulgaris & mugwort & W & & & \\
\hline Celastrus orbiculatus & Oriental bittersweet & $\mathrm{B}$ & M & & \\
\hline $\begin{array}{l}\text { Centaurea biebersteinii } \\
\quad(\text { maculosa })\end{array}$ & spotted knapweed & $\mathrm{B}$ & $\mathrm{S}$ & & \\
\hline $\begin{array}{l}\text { Chamaesyce (Euphorbia) } \\
\text { cyparissias }\end{array}$ & cypress spurge & $\mathrm{B}$ & $\mathrm{S}$ & & \\
\hline Coronilla varia & crown vetch & $\mathrm{B}$ & S & Wa & \\
\hline $\begin{array}{l}\text { Elaeagnus umbellata and } \\
\quad \text { E. angustifolia }\end{array}$ & Russian and autumn olives & $\mathrm{B}$ & M & & \\
\hline Lonicera japonica & Japanese honeysuckle & $\mathrm{B}$ & & & \\
\hline Lythrum salicaria & purple loosestrife & $\mathrm{B}$ & $\mathrm{S}$ & Wa & \\
\hline Phragmites australis & tall reed, common reed & $\mathrm{B}$ & S & W & Wa \\
\hline $\begin{array}{l}\text { Polygonum cuspidatum } \\
\text { (Fallopia japonica) }\end{array}$ & Japanese knotweed & $\mathrm{B}$ & S & Wa & \\
\hline Rhamnus frangula & buckthorn & $\mathrm{B}$ & M & & \\
\hline Rosa multiflora & multiflora rose & $\mathrm{B}$ & & & \\
\hline
\end{tabular}

The usual mode of dispersal of nonnative vascular plant species of concern is treated in Table 2. Most are spread by birds ingesting their fruit who spread the seeds in bird droppings. Wind is the means of dispersal of Ailanthus altissima. Wind is also the most important mode of dispersal for Artemisia vulgaris and Phragmites australis. Most alien taxa can spread by asexual means once they are established. Several woody taxa, notably Ailanthus, Ampelopsis brevipedunculata, Celastrus orbiculatus, and Rosa multiflora can increase rapidly during a growing season by producing copious sucker shoots. The herbaceous aliens (e.g., Artemisia vulgaris and Phragmites) are capable of producing billions of seeds per hectare when their populations are well-established. Even if all the nonnative taxa were eliminated from the Refuge they are all capable of rapid reinvasion.

The criteria used by the National Park Service at JBWR and elsewhere for prioritizing invasive plant species for management follow those developed by the Nature Conservancy (Tu and Meyers-Rice 2002). This study suggests the following procedures:
1. Identify the invasive species.

2. Determine current and potential impact of the invasive species. Species that alter ecosystem processes or outcompete and displace natives, are prioritized over those that do not.

3. Determine current extent of the invasive species. Species poised to invade an area or present only in limited infestations, are dealt with before large but stabilized infestations.

4. Determine the value of the habitat infested by the invasive species. Rare habitats, particularly those that contain rare species, are given top priority.

5. Prepare an experimental design for controlling invasive species. Prepare a map of the area showing GPS coordinates showing the distribution of the nonnative species in question. Decide on the size of the study plots (quadrats) for both experimental treatments and for controls. For woody species with large diameters at breast height [e.g., $\geq 10 \mathrm{~cm}$ (4 in)], quadrats of $10 \mathrm{~m} \times 10 \mathrm{~m}(32.8 \mathrm{ft} \times 32.8 \mathrm{ft})$ may be appropriate. For smaller woody vegetation, including vines, smaller quadrats may be appropriate. For nonwoody (herbaceous)

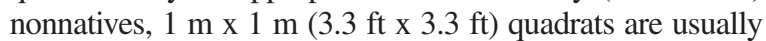
standard. Decide on the number of study plots for controls and experimental treatments. As a general rule, the more study plots the better in terms of the prospect of generating statistically significant results, for example in Analysis of Variance (see a standard statistical text such as Sokal and Rohlf 1995). Time, expense, personnel, and the nature of the habitat itself, will control the number of plots. Generally, however, one needs a minimum of three replicated plots per treatment and per control per habitat type. Depending on the nature of the vegetation, plots may be contiguous or not, and laid out along a line transect that has some environmental meaning such parallel to a path. GPS coordinates should be established for the transect and individual plots. One should assign plots to treatments and controls randomly.

Decide on which plant variables are to be measured at time zero of the project, during the project, and at its termination. These demographic variables may include numbers, size, and height of individual plants, reproductive status, and the birth and death of individual plants. It may also be worthwhile to measure plant growth rates during the course of the experiment.

Decide on how long the experiment is to be performed, such as one growing season), and on how often the study plots are to be monitored. Before the experiment is begun, the method of statistical analysis should be determined, if necessary, in consultation with a biostatistician as a collaborator.

Ailanthus is the most abundant nonnative tree at JBWR (Figure 1). Its seed can be carried great distances by the wind. Once established it can reproduce vegetatively by root sprouts. Steucek (Steucek, pers. comm.) has killed $A i$ lanthus by injecting the trunk with Round Up (glysphosphate). This procedure also kills sprouts from the parent tree.

Three vines, Ampelopsis brevipedunculata, Celastrus orbiculatus, and Lonicera japonica are common at JBWR. All may kill native vegetation in fields, thickets, and woodlands by growing over native vegetation and smothering it. These taxa produce fruit that are eaten by birds and thus dispersed by bird droppings. Seed germination of these taxa may be enhanced by the scarifying process of digestion (Crefting and Roe 1949). 


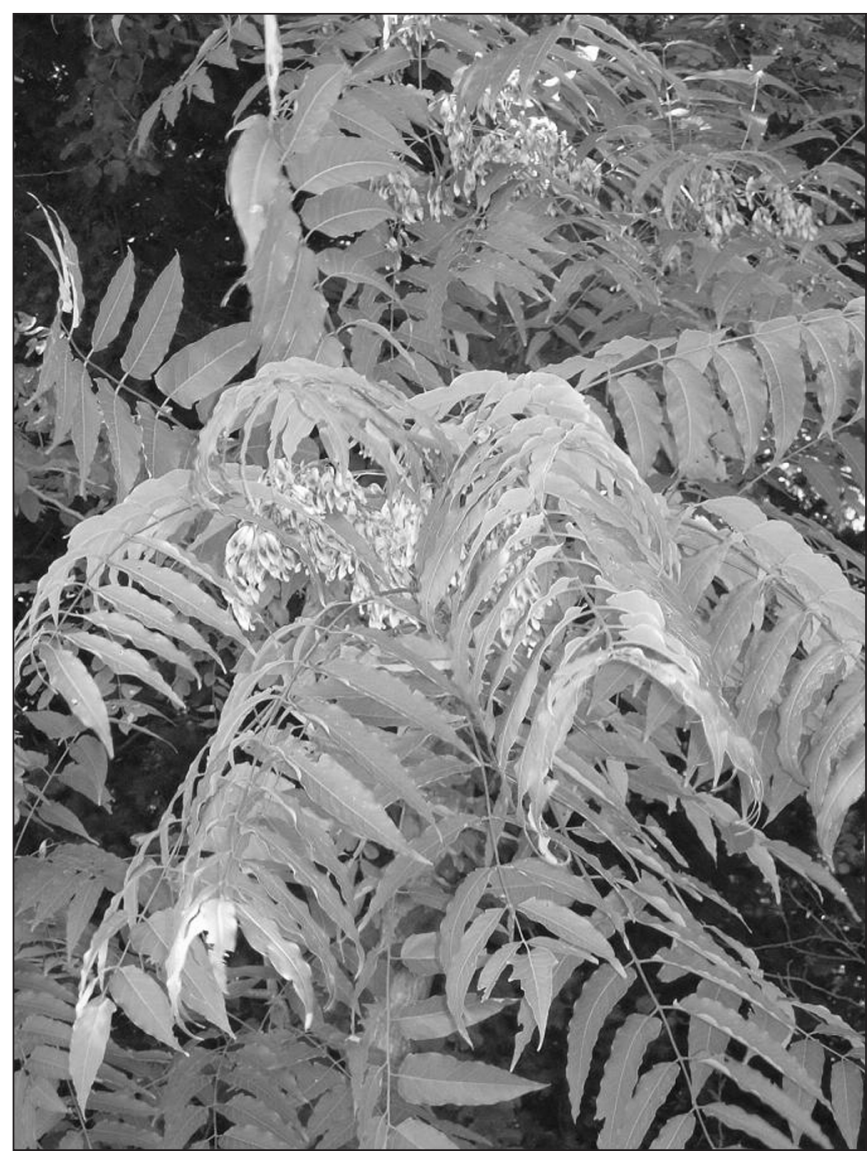

Figure 1. Ailanthus altissima in seed, Jamaica Bay Wildlife Refuge.

Four shrubs, Elaeagnus angustifolia, E. umbellata, Rhamnus frangula, and Rosa multiflora also rely on birds to disperse their seeds. The fruits of these taxa are eaten by migrating birds in the fall and may be deposited kilometers away from their source. When flocks gather, the digested fruit of the above taxa may spread thousands of seeds in a relatively small area within a field or forest. Brief descriptions of the most problematic woody, alien taxa and their possible control, follow.

\section{Ailanthus altissima (tree of heaven)}

A rapidly spreading tree by virtue of its capacity for producing root sprouts and wind dispersed winged seeds from large female trees, occupies considerable area in JBWR that otherwise support native trees. Because it is a dioecious species (separate male and female trees), seed-producing female trees should be eliminated as soon as the sex is determined. It is a rapidly growing small tree with soft wood. It is abundant throughout the refuge by virtue of root sprouts and wind dispersed seed. Trunk injection with Round Up and cutting may be used to control this species.
Ampelopsis brevipedunculata (porcelain berry) Ampelopsis brevipedunculata is a relatively new invader at JBWR. This vine is extremely destructive because it can climb tall trees and kills them by either overgrowing the foliage of the tree (excluding light) or by enhancing the chances the native trees' toppling, mechanical loading, when buffeted by high winds or ice. This destructive vine may be as insidious as a second alien vine, Celastrus orbiculatus. Ampelopsis brevipedunculata may be controlled by selective herbicide treatment, mowing, and cutting.

\section{Celastrus orbiculatus (Oriental bittersweet)}

This is the most abundant woody alien species at JBWR. Like Ampelopsis, this vine overgrows shrubby vegetation and occasionally trees. Crooke's Point has been overrun with tangles of Celastrus excluding the growth of other woody taxa. Cutting, mowing, and selective herbicide treatment may control Celastrus orbiculatus.

\section{Lonicera japonica (Japanese honeysuckle)}

This vine is smaller and slower growing than the preceding vines. Occasionally it grows with the two aformentioned species. It is dominant within some thickets and woodlands. Cutting, mowing, handpulling and herbicide treatment may control Lonicera japonica.

\section{Elaeagnus angustifolia (Russian olive) and $E$. umbellate (autumn olive)}

These two items exist as small trees or large shrubs at the Refuge. Eleagnus umbellata is the dominant species of this pair, at JBWR. Cutting followed by herbicide application to cut stems may effectively eradicate these species.

\section{Rosa multiflora (multiflora rose)}

The thorny canes of this plant can rapidly invade both sunny and shade sites of JBWR. Within a year's time, Rosa multiflora is capable of forming a formidable thicket. Its curved spines can inflict painful wounds and can penetrate thick clothing. It is spread throughout the refuge by birds that feed on the red rose hips. It may be controlled by cutting, mowing, and herbicide treatment.

\section{Rhamnus frangula (buckthorn)}

An exotic woody shrub, this species is of limited distribution within the refuge. This taxon should be eradicated before population size increases, making it difficult to control. The copious cathartic fruits are widely and easily dispersed by birds. Cutting and herbicide treatment are effective means of controlling this species. 
Acknowledgments. For assistance in the identification of several vascular plant species we thank Steven Clemants, Eric Lamont, Robert Meyer, Richard Mitchell, and Gordon Tucker. We appreciate the assistance of Kathy Krause, David Taft, and Donald Riepe for providing historical information on Jamaica Bay Wildlife Refuge. Finally, we appreciate the editorial comments of two anonymous reviewers who greatly improved this manuscript.

\section{LITERATURE CITED}

Black, F.R. 1981. Jamaica Bay History. Gateway National Recreation Area New York, New Jersey Cultural Resources Management Study No. 3. Division of Cultural Resources, North Atlantic Regional Office, National Park Service, U.S. Department of the Interior. 166 pp.

Crefting, L.W., and E.I. Roe. 1949. The role of some birds and mammals in seed germination. Ecological Monographs 19:269-286.

Enright, S.M., and D. Cipollini. 2007. Infection by powdery mildew Erysiphe cruciferum (Erysiphaceae) strongly affects growth and fitness of Alliaria petiolata (Brassicaceae). American Journal of Botany 94:1813-1820.

Gleason, H.A., and A. Cronquist. 1991. Manual of vascular plants of northeastern United States and adjacent Canada, 2nd Ed. New York Botanical Gardens, Bronx, New York. 910 pp.

Kaltman, H. 1968. Field Trip Report. August 30. Jamaica Bay Sanctuary, Broad Channel, N.Y. Bulletin of the Torrey Botanical Club 95:108.

Rheder, A. 1940. Manual of cultivated trees and shrubs hardy in North America, 2nd Ed. MacMillan Co., New York.

Sokal, R.R., and E.J. Rohlf. 1995. Biometry, 3rd Ed. W.H. Freeman, San Francisco.

Stalter, R., and E.E. Lamont. 2002. Vascular flora of Jamaica Bay Wildlife Refuge, Long Island, New York. Journal of the Torrey Botanical Society 129:346-358.

Steucek, G. E-mail message to author, 2007.

Tu, M., and B. Meyers-Rice. 2002. Site Weed Management Plan Template. TNC's Wildland Invasive Species Program. pp. 4-6.

Venezia, K., and R.P. Cook. 1991. Flora of Gateway National Recreation Area. USDI, National Park Service. Gateway National Recreation Area. Directorate Cultural / Natural resources, Fort Wadsworth, Staten Island Unit, Staten Island, New York. 44 pp.

Richard Stalter (corresponding author)

St. John's University - Biological Sciences

Jamaica, New York 11439, U.S.

Dwight Kincaid

Lehman College CUNY - Biological Sciences

Bedford Park Blvd W.

Bronx, New York 10468, U.S.

Michael Byer

Park Botanist

National Park Service - Gateway Nat'l Rec. Area

New York, New York 10305, U.S.
Résumé. Le refuge faunique de la baie de Jamaïque est localisé à l'intérieur de la baie de Jamaïque, une presqu'île dans l'océan Atlantique à l'extrémité ouest de Long Island dans l'état de New York (40 $35^{\circ}$ $\mathrm{N}, 72^{\circ} 52^{1} \mathrm{O}$ ), à l'intérieur des banlieues de Brooklyn et de Queens. La flore vasculaire du refuge se compose de 456 espèces regroupées au sein 270 genres et 90 familles parmi lesquelles 222 sont des espèces non indigènes (soit $49 \%$ de la flore). Les plus agressives des espèces ligneuses sont l'Ailanthus altissima, le Celastrus orbiculatus, le Rosa multiflora, l'Elaeagnus angustifolia, l'E. umbellata, le Rhamnus frangula, le Lonicera japonica et l'Ampelopsis brevipedunculata. L'Ailanthus altissima, l'Ampelopsis brevipedunculata et le Celastrus orbiculatus sont les étrangers les plus agressifs de ceux mentionnés ci haut. Toutes ces espèces peuvent être éliminées de petites surfaces de quelques mètres carrés, et ce en les coupant, par traitement à l'aide d'herbicides ou encore en les arrachant manuellement. Ces espèces invasives s'avèrent à peu près impossible à contrôler, encore moins à éradiquer, du refuge faunique de la baie de Jamaïque. Cet article présente les ligne directrices pour une approche scientifique et expérimentale de ce problème.

Zusammenfassung. Das Naturschutzgebiet Jamaica Bay Wildlife Refuge (JBWR) liegt in der Jamaica Bay, einer Bucht am Westende von Long Island zwischen Brooklyn und Queens. Die Pflanzenwelt des Naturschutzgebiets enthält 456 Arten aus 270 Genera und 90 Familien, von denen 222 Arten (49\% der Flora) nicht endemisch sind. Die stärksten holzigen Eindringlinge sind (Ailanthus altissima), (Celastrus orbiculatus), (Rosa multiflora), (Elaeagnus angustifolia), (E. umbellata), (Rhamnus frangula), (Lonicera japonica), und (Ampelopsis brevipedunculata). Von den genannten Arten sind besonders aggressiv: Ailanthus altissima, Ampelopsis brevipedunculata, und Celastrus orbiculatus. Diese und weitere nicht-endemische Pflanzenarten können auf kleinen Flächen von wenigen Quadratmetern durch Rodung, Herbizide oder Rückschnitt entfernt werden. Es könnte unmöglich sein, diese Pflanzen zu kontrollieren, geschweige denn sie gänzlich zu entfernen. Dieser Artikel nennt einige Richtlinien für einen wissenschaftlichen und experimentellen Ansatz, diesem Problem zu begegnen.

Resumen. El Refugio de Vida Silvestre de Jamaica (JBWR, por sus siglas en inglés) está situado dentro de la Bahía de Jamaica, en el Océano Atlántico, al oeste de Long Island, New York, Estados Unidos (40o35' N de latitud, 72052' W de longitud) entre Brooklyn y Queens, suburbios de New York City. La flora vascular del refugio consiste de 456 especies dentro de 270 géneros y 90 familias de las cuales 222 especies, $40 \%$ de la flora, son exóticas. Las especies maderables más agresivas son: tree of heaven (Ailanthus altissima), Oriental bittersweet (Celastrus orbiculatus), multiflora rose (Rosa multiflora), Russian olive (Elaeagnus angustifolia), autumn olive (E. umbellata), buckthorn (Rhamnus frangula), Japanese honeysuckle (Lonicera japonica), and porcelain berry (Ampelopsis brevipedunculata). Ailanthus altissima, Ampelopsis brevipedunculata, y Celastrus orbiculatus son las más agresivas de las mencionadas. Estas y adicionales especies vasculares maderables no nativas pueden ser removidas de pequeñas áreas de pocos metros cuadrados por medio de la corta, tratamiento con herbicidas o arrancándolas manualmente. Puede ser imposible controlar, mucho menos erradicar estas invasoras del JBWR. Este artículo presenta lineamientos para una aproximación científica y experimental a este problema. 